\title{
MOLECULAR DOCKING TERPINEN-4-OL SEBAGAI ANTIINFLAMASI PADA ATEROSKLEROSIS SECARA IN SILICO
}

\author{
N. M. P. Susanti*, N. P. L. Laksmiani, N. K. M. Noviyanti, K. M. Arianti, dan I K. Duantara \\ Program Studi Farmasi, Fakultas Matematika dan Ilmu Pengetahuan Alam, Universitas Udayana \\ Jalan Kampus Unud-Jimbaran, Jimbaran-Bali, Indonesia \\ *e-mail: dekpitsusanti@unud.ac.id
}

\begin{abstract}
ABSTRAK
Aterosklerosis merupakan penyakit inflamasi kronis yang diawali dengan disfungsi endotel sehingga terjadi penumpukan lemak dan pertumbuhan plak pada dinding dalam arteri. Disfungsi endotel akan mengaktifkan jalur Mitogen Activated Protein Kinase (MAPK) yang melibatkan protein ERK1, ERK2, JNK1, JNK2, dan p38MAPK, serta jalur Nuclear Factor Kappa B (NF-KB) yang melibatkan protein IKK. Terpinen-4-ol merupakan konstituen yang terdapat di dalam rimpang bangle (Zingiber cassumunar Roxb.) yang diketahui memiliki aktivitas antiinflamasi. Tujuan dari penelitian ini adalah untuk mengetahui afinitas dan mekanisme terpinen-4-ol terhadap protein ERK1, ERK2, JNK1, JNK2, dan p38MAPK sebagai antiinflamasi pada aterosklerosis yang dilakukan menggunakan metode molecular docking. Penelitian dilakukan secara eksploratif dengan tahapan preparasi dan optimasi struktur 3D terpinen-4-ol, preparasi struktur 3D protein ERK1, ERK2, JNK1, JNK2, dan p38MAPK, validasi metode molecular docking, serta docking terpinen-4-ol pada proteinprotein tersebut. Hasil docking dinilai dari energi ikatan dan ikatan hidrogen yang terbentuk antara terpinen-4-ol dengan protein. Semakin rendah nilai energi ikatan antara terpinen-4-ol dengan protein target, maka kompleks yang terbentuk semakin stabil. Hasil penelitian menunjukkan bahwa terpinen-4-ol memiliki aktivitas dalam menghambat proses inflamasi karena mampu menghambat protein ERK1, ERK2, JNK1, JNK2, dan p38MAPK dengan nilai energi ikatan masing-masing -5,12; -5,24; -5,08; -5,88; dan -4,99 Kkal/mol. Mekanisme molekuler dalam menghambat aktivitas protein ERK1, ERK2, JNK1, JNK2, dan p38MAPK melalui pembentukan ikatan hidrogen pada protein-protein tersebut. Hasil tersebut memperlihatkan bahwa terpinen-4-ol berpotensi menghambat proses inflamasi sehingga pembentukan plak aterokslerosis dapat terhambat.
\end{abstract}

Kata kunci : aterosklerosis, terpinen-4-ol, molecular docking, in silico

\section{ABSTRACT}

Atherosclerosis is a chronic inflammatory disease that begins with endothelial dysfunction, it caused fat accumulation and plaque growth in the inner arteries walls. Endothelial dysfunction will activate the Mitogen Activated Protein Kinase (MAPK) pathway involving ERK1, ERK2, JNK1, JNK2, and p38MAPK proteins, as well as the Nuclear Factor Kappa B (NF-kB) pathway involving IKK proteins. Terpinen-4-ol is constituent found in the bangle rhizome. The purpose of this study were to determine the affinity and mechanisms of terpinen-4-ol against ERK1, ERK2, JNK1, JNK2, and p38MAPK proteins as anti-inflammatory in atherosclerosis performed using molecular docking method. The study was conducted exploratively with several steps such as preparation and optimization of terpinen-4-ol structure, preparation of 3D ERK1, ERK2, JNK1, JNK2, and p38MAPK proteins, validation method of molecular docking, and docking terpinen-4-ol in these proteins. The docking result are assessed from the binding energy and hydrogen bonds formed between terpinen4-ol and proteins. The smaller value of binding energy terpinen-4-ol with target proteins showed the complex that form more stable. The result showed that terpinen-4-ol and has activity in inhibiting the inflammatory process because it is able to disturb ERK1, ERK2, JNK1, JNK2, and p38MAPK proteins with respective bond energy values $-5,12 ;-5,24 ;-5,08 ;-5,88$; and $-4,99 \mathrm{Kcal} / \mathrm{mol}$. The molecular mechanism in inhibiting the activity of ERK1, ERK2, JNK1, JNK2, and p38MAPK proteins is through the formation of hydrogen bonds in these proteins. These results show that terpinen-4-ol have the potential to inhibit inflammatory process and the formation of atherosclerotic plaque can be obstructed.

Keywords : atherosclerosis, terpinen-4-ol, molecular docking, in silico 


\section{PENDAHULUAN}

Aterosklerosis merupakan penyakit akibat respon inflamasi kronis pada endotel, yang dapat menimbulkan pembentukan dan penebalan plak di dinding pembuluh darah (Warboys, 2011). Disfungsi endotel merupakan faktor utama yang terlibat dalam pertumbuhan plak dan terjadinya aterokslerosis. Dislipidemia merupakan salah satu penyebab terjadinya disfungsi endotel yang menyebabkan meningkatnya permeabilitas sel endotel sehingga memungkinkan terakumulasinya low-density lipoprotein (LDL) pada dinding pembuluh darah (Douglas et al., 2010). Akumulasinya LDL lebih lama dalam jaringan dinding pembuluh darah mempermudah terjadinya modifikasi LDL yang mengakibatkan terbentuknya ox-LDL.

Oksidasi LDL diakibatkan oleh adanya radikal bebas yang bereaksi dengan LDL dan kadar LDL yang tinggi dalam darah (Iuliano dkk., 2000). Timbulnya LDL-Oksidasi ini menstimulasi disfungsi pembuluh darah, menyebabkan ekspresi monocyte chemoathractant protein-1 (MCP-1), macrophage colony-stimulating factor, interferon- $\gamma$, interleukin (IL)-1, IL-6, dan tumor necrosis factor (TNF- $\alpha$ ) serta molekul adhesi meliputi intercellular adhesion molecule (ICAM-1), vascular adhesion molecule (VCAM-1), E-selectin, dan P-selectin yang menyebabkan adhesi serta infiltrasi monosit dan limfosit $\mathrm{T}$ ke daerah intima. Sitokin akan memicu diferensiasi monosit menjadi makrofag dan memfagositosis LDLOksidasi sehingga membentuk sel busa yang berkontribusi dalam terjadinya plak aterosklerosis (Francis and Pierce, 2011; Warboys, 2011). MAPKs merupakan molekul messenger central meliputi Extracellular signal-Regulated Kinase (ERK 1/2), c-jun Nterminal kinase (JNK), dan p38MAPK. Jalur MAPKs berperan dalam memediasi sinyal intraseluler terkait dengan aktivitas seluler meliputi apoptosis, proliferasi, diferensiasi, dan inflamasi. Aktivasi jalur MAPKs diakibatkan oleh adanya proses fosforilasi berbagai macam substrat downstream diantaranya faktor transkripsi, enzim, dan kinase lainnya.

Pengobatan menggunakan bahan alam merupakan salah satu alternatif untuk pengobatan aterosklerosis. Bangle (Zingiber cassumunar Roxb.) merupakan salah satu tanaman yang memiliki kandungan fenilbutanoid, kurkumin, flavonoid, alkaloid, saponin, tanin, steroid, dan terpenoid (Rachmadenawanti dkk., 2016). Terpinen-4-ol merupakan salah satu golongan terpenoid yang merupakan konstituen utama yang terkandung di dalam rimpang bangle (Zingiber cassumunar) dengan kandungan mencapai 30$35 \%$ dari keseluruhan senyawa yang terkandung di dalam rimpang bangle (Bhuiyan, 2018). Hasil uji in vitro menunjukkan bahwa ekstrak etanol Zingiber cassumunar dapat menghambat COX dan produksi matriks metalloproteinase MMP-2 dengan memblokir jalur sinyal proinflamasi yang melibatkan ERK 1/2, JNK, dan p38 pada jalur MAPK (Koontongkaew et al., 2013).

Untuk mengetahui aktivitas terpinen-4-ol sebagai antiinflamasi pada aterosklerosis, maka perlu dilakukan uji pendahuluan menggunakan metode molecular docking secara in silico. Teknik molecular docking secara in silico dapat memprediksi interaksi antara suatu protein dengan ligan secara molekuler, sehingga diketahui aktivitas dari senyawa bioaktif. Metode ini dapat meningkatkan efisiensi dan efektivitas dalam penelitian penemuan obat baru. Oleh karena itu, penelitian ini penting dilakukan untuk mengetahui aktivitas anti aterosklerosis terpinen-4-ol dari rimpang bangle (Zingiber cassumunar) secara in silico.

\section{MATERI DAN METODE}

\section{Bahan}

Bahan yang digunakan yaitu struktur protein ERK1 (PDB ID : 4QTB), ERK2 (PDB ID : 4NOS), JNK1 (PDB ID : 3ELJ), JNK2 (PDB ID : 3NPC), dan p38MAPK (PDB ID : 1OUY) yang diunduh dari website protein data bank http://www.rcsb.org/pdb/home/home.do. serta struktur 3 dimensi terpinen-4-ol yang dibuat dan dipreparasi menggunakan program HyperChem 8.

\section{Peralatan}

Alat yang digunakan dalam penelitian ini yaitu seperangkat komputer dengan spesifikasi Windows 7 (64 bit) dilengkapi program Hyperchem 8, Autodock 4.2, dan Chimera 1.10.1. 
CARA KERJA

Preparasi dan Optimasi Senyawa Terpinen4-ol

Struktur tiga dimensi terpinen-4-ol dibuat dan dioptimasi menggunakan program HyperChem 8. Optimasi struktur dilakukan dengan metode komputasi semi-empiris AM1 dan dilakukan kalkulasi dengan single point serta optimasi geometri.

\section{Preparasi Protein}

Preparasi protein dilakukan dengan memilih protein dalam bentuk aktif yang berikatan dengan native ligand. Selanjutnya native ligand dipisahkan menggunakan program Chimera 1.10.1.

\section{Validasi Metode Molecular Docking}

Validitas metode molecular docking diketahui dengan cara men-docking-kan kembali native ligand pada protein target yang telah mengalami preparasi menggunakan program Autodock 4.2. Metode dikatakan valid apabila nilai Root Mean Square Deviation (RMSD) yang diperoleh $\leq 3 \AA$ (Jain and Nicholls, 2008).

\section{Docking Terpinen-4-ol Pada Protein Target}

Terpinen-4-ol yang telah dioptimasi didocking-kan dengan protein target tanpa native ligand menggunakan program Autodock 4.2 dengan grid box hasil validasi. Molecular docking akan menghasilkan senyawa dengan konformasi tertentu yang memiliki energi ikatan paling rendah untuk berikatan dengan protein target.

\section{Analisis Data}

Data dianalisis berdasarkan hasil energi ikatan yang diperoleh dari molecular docking. Nilai energi ikatan menunjukkan kekuatan ikatan (afinitas) antara senyawa uji dengan protein target. Mekanisme aktivitas senyawa uji dapat diketahui dari jenis interaksi (ikatan hidrogen) yang terbentuk antara terpinen-4-ol dengan protein target.

\section{HASIL DAN PEMBAHASAN}

\section{Preparasi dan Optimasi Struktur 3D Terpinen-4-ol}

Struktur terpinen-4-ol digambar dan dioptimasi menggunakan program Hyperchem 8 dengan metode kalkulasi semiempiris pada model AM1 (Austin model 1). Kalkulasi semiempiris memberikan waktu pengoperasian yang lebih cepat daripada $a b$ initio. Model AM1 merupakan model yang sangat akurat karena parameter-parameter yang diperhitungkan meliputi sifat elektronik, geometri optimasi, total energi, dan pembentukan panas (Hypercube, 2002). Hal tersebut menyebabkan hasil pemodelan AM1 memberikan karakteristik senyawa hasil optimasi lebih mendekati senyawa sintetis (Tahir dkk., 2004). Pada proses optimasi, dilakukan kalkulasi single point dan geometry optimization untuk mendapatkan struktur terpinen-4-ol yang paling stabil dengan energi total terendah. Hasil dari optimasi struktur terpinen-4-ol ditunjukkan pada Gambar 1.

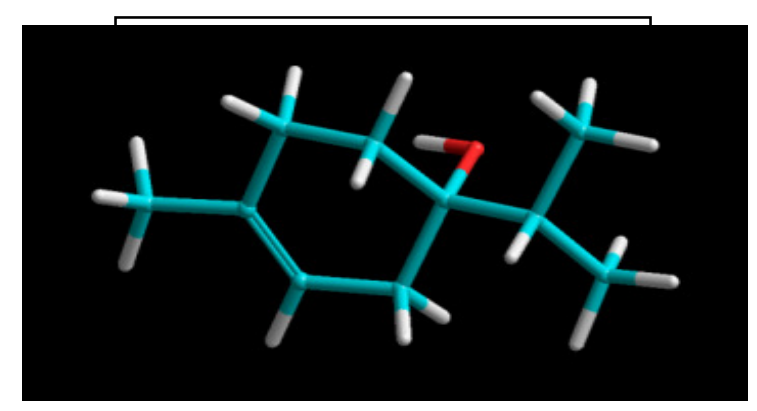

Gambar 1. Struktur Tiga Dimensi Terpinen4-ol Teroptimasi

Besar energi total hasil kalkulasi single point yang diperoleh yaitu $-2892,702163$ $\mathrm{Kkal} / \mathrm{mol}$ dan nilai energi hasil optimasi sebesar -2907,5570 Kkal/mol. Nilai energi hasil optimasi semakin rendah menunjukkan senyawa tersebut memiliki interaksi berupa gaya tarik antar atom yang semakin besar sedangkan gaya tolak antar atom menjadi semakin minimum sehingga konformasi senyawa yang diperoleh semakin stabil (Hypercube, 2002).

\section{Preparasi Struktur 3D Protein Target}

Protein ERK1, ERK2, JNK1, JNK2, dan p38MAPK dipreparasi dengan memisahkan native ligand dari struktur protein menggunakan program Chimera 1.10.1 sehingga dihasilkan masing-masing struktur protein tanpa native ligand-nya dan struktur native ligand yang terpisah seperti pada gambar 2. Pemisahaan native ligand dari struktur protein bertujuan untuk menyediakan pocket yang akan digunakan sebagai ruang tempat berikatan terpinen-4-ol pada kelima protein target. 
Protein ERK2, JNK1, dan p38MAPK memiliki satu rantai dengan native ligand berturut-turut 3,4-dihydroxycinnamic acid (DHC); 2-fluoro-6-\{[2-(\{2-methoxy-4-[ (methylsulfonyl) methyl] phenyl\} amino)-7Hpyrrolo[2,3-d] pyrimidin-4yl] amino benzamide (GS7); dan 1-(2,6- dichlorophenyl)6-[(2,4-difluorophenyl) sulfanyl $]-7-(1,2,3,6-$ tetrahydro-4-pyridinyl)-3,4 dihydropyrido[3,2d] pyrimidin-2(1H)-one (094). Protein ERK1 dan JNK2 merupakan protein dimer yang tersusun atas dua rantai identik. Rantai yang digunakan yaitu rantai $\mathrm{A}$ dengan native ligand masing-masing (3R)-1-(2-oxo-2-\{4-[4(pyrimidin-2-yl) phenyl] piperazin-1-yl\} ethyl)$\mathrm{N}$-[3-(pyridin- 4- $\quad y l$ )-2H-indazol-5-yl] pyrrolidine-3-carboxamide (38Z) dan 1-(5tert-butyl-2-p-tolyl-2H-pyrazol-3-yl)-3- [4-(2morpholin-4-yl-ethoxy)-naphthalen-1-yl]-urea (B96).

Pada proses preparasi protein, dilakukan juga penghilangan molekul air $\left(\mathrm{H}_{2} \mathrm{O}\right)$ disekitar struktur protein. Hal tersebut bertujuan agar molekul air tidak mengganggu proses docking, sehingga dapat dipastikan yang berinteraksi hanya ligan dengan protein (Tjahyono dan Hamzah, 2013). Native ligand dan protein yang telah dipreparasi kemudian disimpan dalam format file .pbd.

\section{Validasi Metode Molecular Docking}

Validitas metode molecular docking diketahui dengan cara men-docking-kan kembali (redocking) native ligand pada protein terget menggunakan program Autodock 4.2. Proses validasi metode molecular docking yang pertama dilakukan yaitu menambahkan atom hidrogen pada protein target yang sudah memiliki pocket cavity. Penambahan hidrogen bertujuan untuk menyesuaikan suasana docking agar mendekati suasana $\mathrm{pH}$ di dalam tubuh (Drie, 2005). Selain itu, penambahan atom hidrogen memiliki tujuan untuk memunculkan kembali atom hidrogen pada makromolekul sehingga ikatan hidrogen yang terbentuk dapat teramati (Sastry et al., 2013).

Dalam validasi metode molecular docking, dilakukan juga pengaturan grid box yang akan menjadi ruang untuk native ligand membentuk konformasi ketika di-docking-kan dengan protein target. Grid box merupakan tempat dimana ligan akan berinteraksi dengan residu asam amino pada protein target. Penentuan grid box dilakukan untuk mengetahui titik koordinat pada binding site dari suatu protein. Pengaturan grid box yang dilakukan adalah pengaturan koordinat grid center dan pengaturan grid size (Rachmania dkk., 2016).

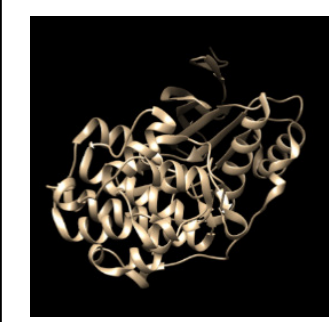

(1)

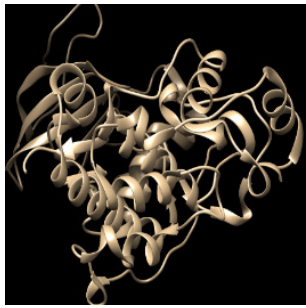

(2)

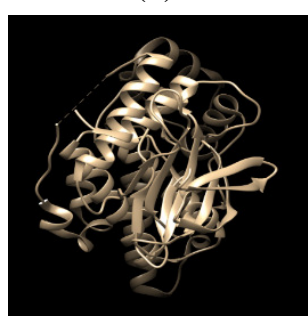

(3)

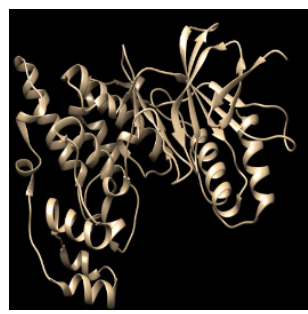

(4)

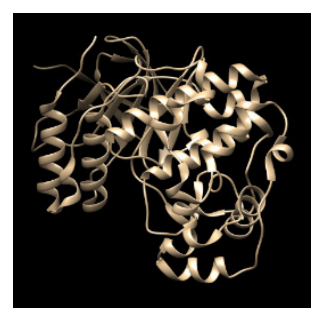

(5)

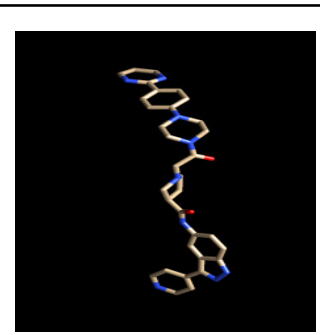

(a)

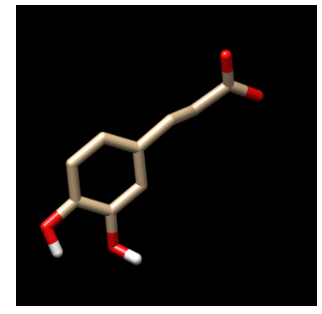

(b)

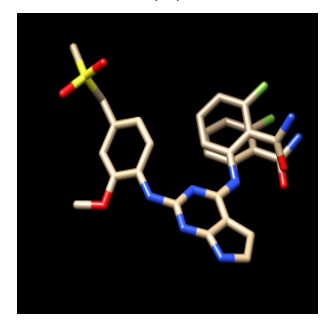

(c)

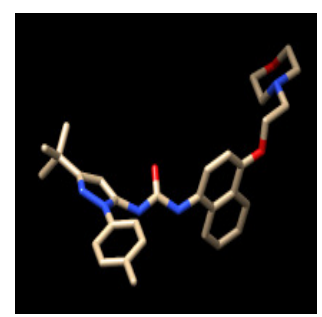

(d)

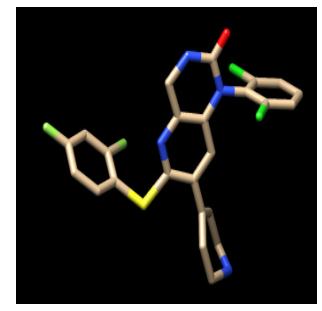

(e)
Keterangan

$1:$ Protein ERK1 a : native ligand ERK1

2 : Protein ERK2 $\quad \mathrm{b}:$ native ligand ERK2

3 : Protein JNK1 c : native ligand JNK1

4 : Protein JNK2 d : native ligand JNK2

5 : Protein $\mathrm{p} 38 \mathrm{MAPK} \mathrm{e}:$ native ligand $\mathrm{p} 38 \mathrm{MAPK}$

Gambar 2. Struktur Tiga Dimensi Protein Target dan Native Ligand 
Proses redocking dilakukan dengan metode semirigid, yaitu mengatur agar makromolekul bersifat rigid sehingga tidak terjadi pengubahan bentuk binding site selama proses redocking sedangkan ligan yang akan di-docking-kan bersifat fleksibel (Tjahjono dan Hamzah, 2013). Parameter validasi dalam molecular docking berupa nilai Root Mean Square Deviation (RMSD). RMSD menunjukkan perbandingan konformasi native ligand hasil docking dengan konformasi native ligand hasil pengukuran kristalografi (Saputri dkk., 2016). Batas nilai RMSD yang dapat diterima adalah $\leq 3 \AA$ (Jain and Nicholls, 2008). Nilai RMSD yang diperoleh untuk protein ERK1, ERK2, JNK1, JNK2, dan p38MAPK

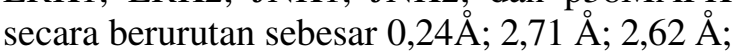
0,62 Å; dan 1,60 ̊̊. Berdasarkan hasil tersebut, metode yang digunakan dapat dikatakan valid sehingga proses docking terpinen-4-ol dapat dilakukan. Nilai RMSD, energi ikatan, dan residu asam amino yang membentuk ikatan hidrogen dengan native ligand ditunjukkan pada Tabel 1.

Tabel 1. Hasil Redocking Native Ligand pada Protein Target

\begin{tabular}{|c|c|c|}
\hline Protein & $\begin{array}{c}\text { Energi } \\
\text { Ikatan } \\
\text { (Kkal/mol) }\end{array}$ & $\begin{array}{c}\text { Residu } \\
\text { Asam } \\
\text { Amino }\end{array}$ \\
\hline ERK1 & $-14,98$ & $\begin{array}{c}\text { Lys71 } \\
\text { Met125 } \\
\text { Lys131 }\end{array}$ \\
\hline ERK2 & $-5,97$ & $\begin{array}{c}\text { Lys54 } \\
\text { Met108 } \\
\text { Asp167 }\end{array}$ \\
\hline JNK1 & $-8,80$ & $\begin{array}{l}\text { Met111 } \\
\text { Asn114 }\end{array}$ \\
\hline JNK2 & $-15,21$ & $\begin{array}{l}\text { Met111 } \\
\text { Asp169 }\end{array}$ \\
\hline P38MAPK & $-10,24$ & $\begin{array}{l}\text { Met109 } \\
\text { Gly110 }\end{array}$ \\
\hline
\end{tabular}

Berdasarkan hasil redocking, dapat diketahui energi ikatan native ligand dengan protein ERK!, ERK2, JNK1, JNK2, dan p38MAPK secara berurutan sebesar -14,98 $\mathrm{Kkal} / \mathrm{mol}$; -5,97 Kkal/mol; $-8,80 \mathrm{Kkal} / \mathrm{mol}$; $-15,21 \mathrm{Kkal} / \mathrm{mol}$; dan $-10,24 \mathrm{Kkal} / \mathrm{mol}$. Selain itu, dapat diamati residu yang membentuk ikatan hidrogen dengan native ligand. Pada protein ERK1, native ligand membentuk ikatan hidrogen dengan residu Lys71, Met125, dan Lys131. Pada protein ERK2, terbentuk tiga ikatan hidrogen, yaitu antara native ligand dengan residu Lys54, Met108, dan Asp167.
Dua ikatan hidrogen terbentuk antara native ligand dengan protein JNK1 yang terjadi dengan residu Met111 dan Asn114. Protein JNK2 membentuk dua ikatan hidrogen dengan native ligand, yaitu antara native ligand dengan residu Met111 dan Asp169. Native ligand dapat membentuk dua ikatan hidrogen dengan protein p38MAPK, yaitu dengan residu Met109 dan Gly 110. Interaksi lain yang teramati dalam redocking juga meliputi gaya van der Waals dan interaksi elektrostatik. Visualisasi interaksi yang terjadi antara native ligand dengan protein target ditampilkan pada Gambar 3.

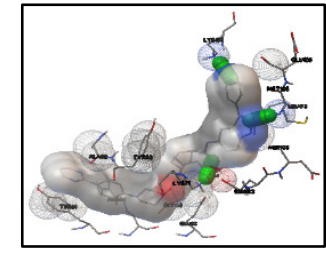

(1)

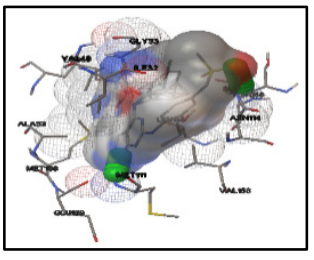

(3)

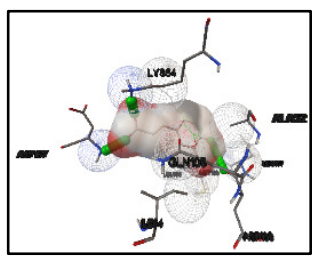

(2)

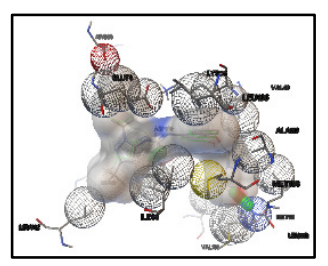

(4)

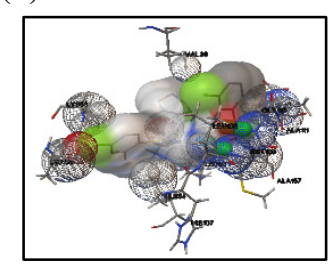

(5)

Keterangan :

1: Konformasi native ligand pada protein ERK1

2: Konformasi native ligand pada protein ERK2

3 : Konformasi native ligand pada protein JNK1

4: Konformasi native ligand pada protein JNK2

5 : Konformasi native ligand pada protein $\mathrm{p} 38 \mathrm{MAPK}$

Gambar 3. Visualisasi Interaksi antara Native Ligand dengan Protein Target

Berdasarkan Gambar 3, dapat dilihat interaksi yang terjadi antara native ligand dengan protein target meliputi ikatan hidrogen (silinder berwarna hijau), gaya van der Waals (bola bergaris), serta interaksi elektrostatik. Interaksi elektrostatik yang terjadi akibat atom $\mathrm{O}$ (bagian berwarna merah), $\mathrm{N}$ (bagian berwarna biru), $\mathrm{Cl}$ (bagian berwarna hijau muda), dan $\mathrm{F}$ (bagian berwarna kuning kecoklatan). Volume senyawa digambarkan dengan bulatan berwarna abu-abu. 


\section{Docking Terpinen-4-ol pada Protein Target}

Penambatan molekul terpinen-4-ol pada protein target dilakukan menggunakan program Autodock 4.2 dengan ukuran grid box dan koordinat yang diperoleh saat validasi metode. Metode yang digunakan dalam docking terpinen-4-ol sama dengan ketika validasi metode, yaitu semirigid. Berdasarkan hasil docking terpinen-4-ol, diperoleh 10 konformasi ikatan antara terpinen-4-ol dengan protein ERK1, ERK2, JNK1, JNK2, dan p38MAPK.

Hasil yang diperoleh dari docking terpinen-4-ol berupa energi ikatan dan jenis interaksi (ikatan hidrogen). Energi ikatan yang terbentuk merupakan kalkulasi (scoring function) dari konformasi ligan (I) yang terbentuk pada suatu makromolekul (E) saat kondisi ekuilibrium (conformational search). Berdasarkan kedua variabel tersebut, dikalkulasikan (scoring function) nilai dari kompleks $[\mathrm{E}+\mathrm{I}]=[\mathrm{EI}]$ yang dikenal sebagai energi ikatan atau energi Gibbs $(\Delta \mathrm{G})$. Energi tersebut berkaitan dengan afinitas ligan terhadap protein (Kitchen et al., 2004). Nilai energi ikatan yang rendah menunjukkan kompleks ligan-protein yang terbentuk stabil (Manna et al., 2017). Berdasarkan hal tersebut maka dipilih konformasi senyawa uji yang memiliki energi ikatan terendah dan berinteraksi dengan residu asam amino pada binding site. Energi ikatan, jenis interaksi (ikatan hidrogen), dan residu yang membentuk ikatan hidrogen ditunjukkan pada Tabel 2.

Tabel 2. Hasil Docking Terpinen 4-ol pada Protein Target

\begin{tabular}{ccc}
\hline Protein & $\begin{array}{c}\text { Energi } \\
\text { Ikatan } \\
\text { (Kkal/mol) }\end{array}$ & $\begin{array}{c}\text { Residu } \\
\text { Asam } \\
\text { Amino }\end{array}$ \\
\hline ERK1 & $-5,12$ & Lys71 \\
ERK2 & $-5,24$ & Met108 \\
JNK1 & $-5,08$ & Asp106 \\
JNK2 & $-5,88$ & Asp111 \\
P38MAPK & $-4,99$ & Met109 \\
\hline
\end{tabular}

Berdasarkan hasil docking terpinen-4-ol, dapat diketahui jika energi ikatan terpinen-4-ol dengan protein target lebih tinggi daripada energi ikatan native ligand dengan protein target. Nilai energi ikatan yang semakin rendah menunjukkan afinitas senyawa terhadap protein target semakin kuat (Azis dkk., 2016). Berdasarkan data tersebut, terpinen-4-ol memiliki afinitas yang lebih lemah daripada native ligand.

Terpinen-4-ol dapat membentuk ikatan hidrogen dengan residu Lys71 pada protein ERK1. Terbentuk dua ikatan hidrogen antara terpinen-4-ol dengan protein ERK yang terjadi pada residu Met108 dan Asp106. Pada protein JNK1, terbentuk ikatan hidrogen antara terpinen-4-ol dengan residu Met111. Terpinen-4-ol membentuk satu ikatan hidrogen pada protein JNK2, yaitu dengan residu Asp169. Pada protein p38MAPK, terpinen-4-ol membentuk ikatan hidrogen dengan residu Met109 dan His107. Visualisasi interaksi yang terjadi dapat dilihat pada gambar 4 .

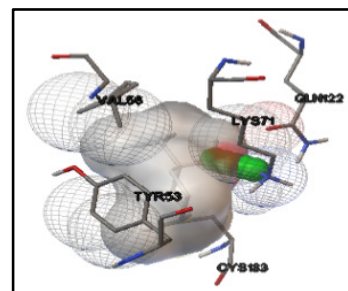

(1)

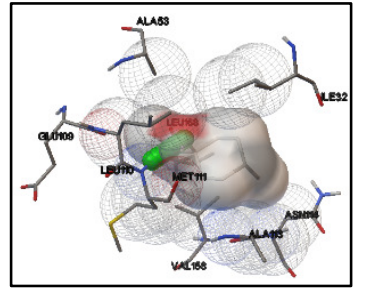

(3)

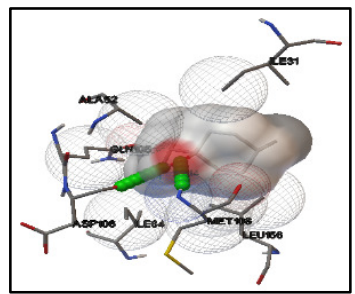

(2)

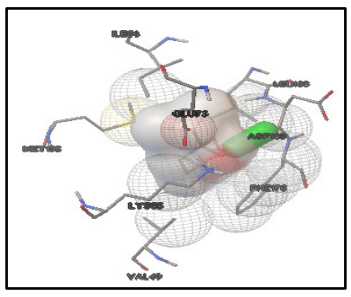

(4)

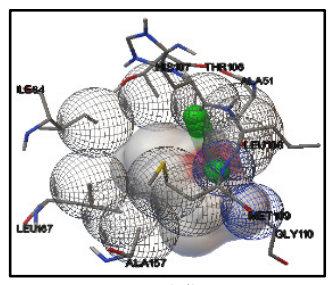

(5)

Keterangan :

1 : Konformasi terpinen-4-ol pada protein ERK1

2 : Konformasi terpinen-4-ol pada protein ERK2

3 : Konformasi terpinen-4-ol pada protein JNK1

4 : Konformasi terpinen-4-ol pada protein JNK2

5 : Konformasi terpinen-4-ol pada protein p38MAPK

$\begin{array}{llrr}\text { Gambar 4. } & \text { Visualisasi } & \text { Interaksi } & \text { antara } \\ & \text { Terpinen-4-ol } & \text { dengan } & \text { Protein } \\ & \text { Target } & & \end{array}$ 


\section{SIMPULAN DAN SARAN}

\section{Simpulan}

Terpinen-4-ol memiliki potensi sebagai antiinflamasi pada aterokslerosis secara molekular karena memiliki afinitas dengan protein ERK1, ERK2, JNK1, JNK2, dan p38MAPK dengan nilai energi ikatan berturutturut 5,$12 ;-5,24 ;-5,08 ;-5,88 ;-4,99 ;-4,89$ $\mathrm{kkal} / \mathrm{mol}$, sehingga dapat menghambat protein ERK1, ERK2, JNK1, JNK2, dan p38MAPK.

\section{Saran}

Perlu dilakukan uji secara in vitro dan in vivo untuk melihat kemampuan serta efektifitas dari terpinen-4-ol sebagai antiaterosklerosis.

\section{UCAPAN TERIMAKASIH}

Penulis mengucapkan terimakasih kepada dosen-dosen pembimbing, keluarga penulis, teman-teman dan semua pihak yang telah sangat membantu dalam penelitian ini.

\section{DAFTAR PUSTAKA}

Azis, F.K., Nukitasari, C., Oktavianingrum, F.A., Ariyati, L.W., dan Santoso, B. 2016. Hasil In Silico Senyawa Z12501572, Z00321025, SCB5631028 dan SCB13970547 Dibandingkan Turunan Zerumbon terhadap Human Liver Glycogen Phosphorylase (115Q) sebagai Antidiabetes. Jurnal Kimia Valensi, 2(2):120-124.

Bhuiyan, N. I., Chowdhury, J. U. and Begum, J. 2018. Volatile Constituents of Essential Oils Isolated from Leaf and Rhizome of Zingiber cassumunar Roxb, Bangladesh Journal of Pharmacology, 3:69-73.

Drie, J. H. V. 2005. Pharmacophore-Based Virtual Screening : A Practical Perspective, Alvarez, J. and Schoicet, B. Virtual Screening in Drug Discovery. Taylor and Francis Group, Boca Raton, 157-205.

Douglas, G., Channon, K.M. 2010. The Pathogenesis of Atherosclerosis. Medicine, 38(8): 397-402.

Francis, A. A. and Pierce, G. N. 2011. An Integrated Approach dor The Mecanism
Responsible for Atherosclerotic Plaque Regression. Experimental and Clinical Cardiology, 16(3):77-86.

Hypercube. 2002. HyperChem Release 7: Tools for Molecular Modeling, Ontario: Hypercube Incorporation,.

Jain, A. N. and Nicholls, A. 2008. Recommendations for Evaluations of Computational Methods. J. Comput. Aided Mol. Des., 22:133-139.

Kitchen, D. B., Decornez, H., Furr, J. R. and Bajorath. J. 2004. Docking and Scoring in Virtual Screening for Drug Discovery. Nat. Rev. Drug. Discov., 3(11):935-949.

Koontongkaew, S., Meesuk, L., Aupaphong, V., Dechatiwongse Na Ayudhya, T. and Poachanukoon, O. 2013. Inhibitory Effect of Zingiber cassumunar Extract on Lipopolysa200ccharide-Induced Cyclooxygenase-2 and Matrix Metalloproteinase Expression in Human Gingival Fibroblasts. $J$ Periodont, 48:507-516.

Manna, A., Laksitorini, M.D., Hudiyanti, D. and Siahaan, P. 2017. Molecular Docking of Interaction between ECadherin Protein and Conformational Structure of Cyclic Peptide ADTC3 (AcCADTPC-NH2) Simulated on 20 ns. Journal of Scientific and Applied Chemistry, 20(1):30 - 36.

Rachmadenawanti, E., Hermansyah, B., Hermansyah Y. 2016. Uji Aktivitas Fraksi Diklorometana Ekstrak Metanol Bangle (Zingiber cassumunar Roxb.) sebagai Terapi Komplementer Malaria secara In Vitro. e-Jurnal Pustaka Kesehatan, 4(2):205-209.

Rachmania, R. A., Supandi, dan Cristina, F. A. D. 2016. Analisis Penambatan Molekul Senyawa Flavonoid Buah Mahkota Dewa (Phaleria macrocarpa (Scheff.) Boerl.) pada Reseptor $\alpha$-Glukosidase sebagai Antidiabetes. Pharmacy, 13(2):239-251.

Saputri, K..E., Fakhmi, N., Kusumaningtyas, E., Priyatama, D. dan Santoso, B. 2016. Docking Molekular Potensi Anti Diabetes Melitus Tipe 2 Turunan Zerumbon Sebagai Inhibitor Aldosa Reduktase Dengan Autodock-Vina. Chimica et Natura Acta, 4(1):16-20.

Sastry, G. M., Adzhigirey, M., Day, T., Annabhimoju, R. and Sherman, W. 2013. Protein and Ligand Preparation: 
Parameters, Protocols, and Influence on Virtual Screening Enrichments. J. Comput. Aided Mol. Des., 27(3):221234.

Tahir, I., K. Wijaya, Falah, I.I., dan Damayanti, R. 2004. 'Pemodelan Molekul Senyawa Mycosporine-Like Amino Acids (MAAs-Like) sebagai Senyawa Penyerap Sinar UV', dipresentasikan pada Seminar Nasional Hasil Penelitian MIPA di Semarang, 4 Desember.
Tjahjono, D. H., dan Hamzah, N. 2013. Studi Hubungan Kuantitatif StrukturAktivitas, Fitur Farmakofor, dan Docking Molekuler Senyawa Turunan Pirazolo-[3,4-d]-Pirimidin sebagai Inhibitor Mer Tirosin Kinase. Acta Pharmaceutica Indonesia, 38(1):1-10.

Waraboys, C. M., Amini, N., Luca, A. D. and Evans, P. C. 2011. The Role of Blood Flow in Determining The Sites of Atherosclerotic Plaque. F1000 Report Medicine, 3(5):1-8. 